\title{
THE EFFECT OF TEMPORAL CONJUNCTION MASTERY AND STUDENTS' ACHIEVEMENT IN WRITING PROCEDURE TEXT OF THE 2017/2018 ELEVENTH YEAR STUDENTS OF SMA SWASTA PERSIAPAN STABAT
}

\author{
Ayu Indari, Rika Rahma Diana Barus \\ STKIP Budidaya Binjai
}

The objective of this study was to find out the effect of temporal conjunction mastery and students' achievement in writing procedure text of the 2017/2018 eleventh year students of SMA Swasta Persiapan Stabat were divided into two classes. They were XI IPA ${ }^{1}$ and XI IPA $^{2}$. There are 60 students. That number then became the sample of this research. The design of the study was categorized as an experiment quantitative research. It meant there were two groups. They were experimental group that received treatment. This study was conducted by an experimental research. It aimed to measure the students' ability on descriptive writing. Writing is one of four basic skills. And it is one productive skill in English. It is very important in studying English. The writers used the written test. The writers, as the learning input in understanding the nature of procedure text and the ways to teach procedure text for Senior High School Students effectively and efficiently. The data were acquired by using written test. The test consisted of two types; they were pre-test and post-test. After analyzing the data, the finding indicates that result of analysis was 3.50. It was found out that observed was higher than $t$-table or it can be said $(3.50>2.002 ; \alpha=0.05)$. It means that temporal conjunction mastery and students' achievement in writing procedure text of the 2017/2018 eleventh year students of SMA Swasta Persiapan Stabat.

Keywords: Temporal conjunction mastery, writing procedure text.

\section{INTRODUCTION}

Everybody in this world has language, because language is very important thing for us. Without language the people cannot communicate to other. There are a lot of languages in the world such as French, Japanese, Arabic, English, etc. English is the world's most important and widely used language. Language authentically means for a tool of communication as what every single person believes so far. According to Wareing in Thomas (2004:6), "Language is a systematic way of combining smaller units into larger units for the purpose of communication." The communication itself defines as something we need to conduct in creating an interaction to other people based on the practical scopes. And language is essentially a rule-governed system of this kind, but there are other ways of thinking about how language works and what we do with it (Thomas, 2004:6).

Furthermore, Halimatussakdiah (2011:1) ever states that language cannot be separated from our lives because it is used to connect society. We can also describe our ideas, feelings and desires to other people using the language. In conclusion, the recent quotation truly leads our mind in order to understand that language comes onto the surface in building a line of communication which the purpose is to goal by deserving and using the whole approaches and medias; include the four main skill in language among others speaking, listening, reading and writing. As Peregoy and Boyle (2001:107) state that listening, speaking, reading and writing also occur naturally together in learning events in school at all grade levels, even though traditionally they were taught separately.

The communication of the world definitely needs a central language as a media to introduce one group to other group in the same world it heads for English. According to Quirk (2005:3), English is generally acknowledged to be the world's most important language. It is perhaps worth glancing briefly at the basis for that evaluation. There are, after all, thousands of different languages in the world, and each will seem uniquely important to 
those who speak it as their native language, the language they acquired at their mother's knee. But there are more objective standards of relative importance.

Furthermore, English comes as a container to apply and process an understanding of language all over the world. The multilingual societies who always contact and interacts each other are absolutely looking forward to using English as their most widely and officially used language. A distinction is often made that depends on how the language is learned: as a native language (or mother tongue), acquired when the speaker is a young child (generally in the home), or as a nonnative language, acquired at some subsequent period. Overlapping with this distinction is that between its use as a first language, the primary language of the speaker, and as an additional language. In some countries (particularly of course where it is the dominant native language), English is used principally for internal purposes as an international language, for speakers to communicate with other speakers of the same country; in others it serves chiefly as an international language, the medium of communication with speakers from other countries. In case of the terms when they are setting somewhere in other parts of the world and trying to communicate with others, most of the social humans utilize English to be the best linguistic agent in the aims of understanding each other.

In Indonesia, English education holds the crucial meaning to learn. English has been an obligatory and important subject to be taught to the students at every school starting from junior high school until the university level. That it appears to public when the government really needs the society producing the better generation to face the world forward. But unfortunately the education system which is dominantly used by the most of English teachers in Indonesia is an old-fashioned or conventional technique (approach).

Students basically have their personal interest to learn more and more in gaining much new information from people around them from their teacher for instance. In junior high school, English teachers are demanded (even commanded) to share the subject based on the basic competences at the curriculum of English subject. As what has been stated and listed in the standard of content, the students of junior high school should be able to master and comprehend at least five types of text namely narrative, recount, descriptive, procedure and report text. These texts are discussed in improving the students' language skills.

Thereby, comprehending the procedure text is indeed one of the competences that students of junior high school should achieve. That in accordance with Warner (2009:34), procedure text is designed to tell the reader how to do something. It explains how people perform different processes in a sequence of steps for example; the process of cooking kebab, making a cup of cappuccino, taking a levitation photo and so on.

To understand a procedure text, the students should be familiar with the generic structure and linguistic features which are identically used in the text. This text uses action verbs and simple present tense, which often looks as imperative sentences. It also uses the temporal conjunctions such as first, second, then, next, finally, etc. The use of temporal conjunctions or transition signals as people usually call is very significantly important. Temporal conjunctions act like signposts to indicate to the reader the order and flow of the writer's ideas. They help carrying over a thought from one sentence to another, from one paragraph to another, of from one idea to another. They can show the steps or the procedures of the process in making something. By reading the temporal conjunctions, the reader can follow the steps one by one. And they will know what to do next.

In accordance with the situation occurring in the range, students still had several problems in procedure text writing. Based on, since the text tell how to do or use something, the students still got confused to define what the temporal conjunctions really are and how the good application they use appropriately in a procedural text as they did not realize that temporal conjunctions play an important role in arranging and explaining the steps. The previous research review, Esther Geva, the title "Reading Comprehension in a Second Language: The Role of Conjunctions", and Eka Febriani, the tittle "Improving students' skills in writing procedure texts by using picture series for the seventh grade students of SMP Negeri 3 Mertoyudanin the academic year of 2013/2014". Both of the previous research, they discussed about various variable namely conjunction and procedure text into several 
problems. Based on the previous research, the writer would like to find out those variables in another context.

\section{Literature Review}

\section{A. Temporal Conjunctions}

Literally, temporal conjunctions are used to join or connect one statement to another one with a particular transition signal as what writer has mentioned on the previous page. The use of conjunctions here is to be the relater between two successive sentences that is their relation in external terms, as content may be simply one of sequence in time: the one is subsequent to the other. This temporal relation is expressed in its simple form by then. Look at the following instance below:

(Alice) began by taking the little golden key, and unlocking the door that led into the garden. Then she set to work nibbling at the mushroom... till she was about a foot high: then she walked down the little passage: and then she found herself at last in the beautiful garden.

The understanding of temporal conjunctions apparently does not only get into the terms then or and then, but it also comes with the other expressions such as next, afterwards, after that, subsequently, following, at once, thereupon, on which, presently, all this time and a number of other forms. Here below the examples:

"But that must happen very often," Alice remarked thoughtfully. "It always happens," said the Goat. After this, Alice was silent for a minute or two, pondering.

...she heard a little shriek and a fall, and a crash of broken glass, from which she concluded that it was just possible it had fallen into a cucumber-frame, or something of the sort. Next came an angry voice the Rabbit's "Pat! Pat! Where are you?" And then a voice she never heard before,...

The temporal conjunctions' relation may be made more specific by the presence of an additional component in the meaning, as well as that of succession in time. So, for example, the combination of conjunctions "then + immediately" (at once, thereupon, on which); "then + after an interval" (soon, presently, later, after a time); "then + repetition" (next time, on another occasion); "then + a specific time interval" (next day, five minutes later) and so on. Examples:

"Tickets, please!" said the Guard, putting his head in at the window. In a moment everybody was holding out a ticket.

"You alarm me!" said the King. "I feel faint Give me a ham-sandwich!" On which the Messenger, to Alice's great amusement, opened a bag that hung round his neck, and handed a sandwich to the King, who devoured it greedily.

In all these instances the external temporal relation is paralleled by the sequence of the sentences themselves: the second sentence refers to a later event. But this is not necessarily the case; the second sentence may be related to the first, still by means of temporal cohesion, through an indication that it is simultaneous in time, or even previous. And a conclusion the writer may draw here is that temporal conjunctions have made an enormous effect and relationship among the unit of a text on the setting of time when an event happens.

In a Lightbrown's point of view, he states the marking of temporal relationships appears to be one of the more difficult feats of the toddler's language development. Although the first conjunctions appear before two years of age, changes continue into the school years. These changes appear not merely to be based on semantic differentiation; they reflect shifts in the organization of discourse. This study addresses the differences in pragmatic context which affect clause order, choice of sequencing conjunctions and the verb forms within conjoined clauses in the period between two and eight.

All temporal conjunctions relate one event to another, either sequentially or simultaneously. One event is the reference time for the other. Weist's argument helps us to see why temporal answers to temporal questions are acquired so late in comparison to other $w h$ - questions they call for reference time responses. In Weist's (2000:241) view, the onset of a three-time system with speech time, event time and reference time distinguished may be related to knowledge of scripts for familiar events. 
The development of marking of temporal relationships is a slow process. Time perception is more conceptual, less visible than spatial perception, less available to comparison and consensus; even older second language learners are slower to learn time than space language. Hereby, the conclusion is most of the junior students at school only comprehend the using of spatial conjunction (including adverb of place) due to the real and concrete appearance. While the trouble of using the temporal conjunction is less understandable to learn as the appearance of the related materials needs an abstract and invisible comprehension.

\section{B. Writing Procedure Text}

Based on the generic structure and linguistic features dominantly used, texts are divided into several types. They are narrative, recount, descriptive, report, procedure, explanation, analytical exposition, hortatory exposition, discussion, review, anecdote, spoof and news item. These variations of text are also called as genre.

In the English curriculum of junior high school, there are only five of them which are taught, namely narrative, recount, descriptive, report and procedure text. In this study, the writer focuses the discussion only on one of them, which is procedure text.

According to Kier (2009:8), procedure text is a type of text which tells the reader how to make or do something. While as mentioned in a website, procedural text is the set of steps which should be completed in the right sequence to get the goal. And that is why a procedural context absolutely gives short, clear instructions to enable the reader to achieve a goal. In addition, this text explains how to do something through a series of steps (Anderson,2007:52).

As the main purpose of a procedure text is to direct, inform and explain, Anderson and Anderson (2007: 52) also add to explain that the social function of procedure text is to explain how something can be done such as directions, recipes, instruction manuals and itineraries.

Procedures must serve a purpose or an aim or a goal and must be appropriate for an audience such as a child or adult. Procedures may be spoken, written or visual and can take place face to face, in a written form or in the media. While most involve physical activity, many relate to mental or emotional behavior such as how to play in a sportsmanlike manner.

There are different types of procedure texts serving different purposes. Procedures can instruct how to do a particular activity, for example stage directions and operating machinery, or explain the progression of an activity, e.g. dance steps and meeting agendas. Procedures normally take the form of directions or instructions. Directions depend on someone with the knowledge having the skills to pass them on accurately, and will direct someone to a place. Instructions will methodically explain how to make or do something, how something works or how it is used. Examples would be instruction manuals or operating instructions.

People are involved in many activities which include playing games and sports, making and putting on clothing, using equipment, assembling and operating machinery, making recipes, diagrams, science experiments or craft creation, following appliance manuals and instruction manuals, directions and rules of games. All of these require procedural texts so that the rules, process or stages can be clearly communicated.

Therefore, the generic structure of procedure text contains:

a) An introductory statement that gives the aim or goal which we want to do.

b) A list of the materials that will be needed to complete the procedures.

c) A sequence of oriented steps in the order they need to be done to achieve the goal.

While the linguistic features of a procedure text are:

a) Using Simple Present Tense

b) Using an imperative form, for examples: prepare mushrooms, add some sugar, etc.

c) Using mainly of temporal conjunctions (connectives), for examples to indicate sequence especially in spoken text like first or firstly, second or secondly, and to indicate sequence in written text such as then..., after that ..., etc.

d) Using action verbs (material process), for examples: take, put, cut, pour, etc. 
e) Using adverbials to clarify the time, place or manner, for examples: wait for fifteen minutes, mix thoroughly, stirring gently, etc.

\section{METHODS}

This study was conducted in SMA Swasta Persiapan Stabat. The writers choose this school as the location of the study due to the fact that it was very much possible to have a research. The location of this study was chosen because: to the knowledge of the researcher, this title has not been investigated in the school. This study was an experimental design. This was used because the writer gave treatments to the sample in order to know the result of the study before and after the treatments were given. There was only one group student. The writer gave pretest before the treatment and posttest after the treatment. Then the results of the two tests were compared to see the difference.

In this study, the population of the research was the whole 2017/2018 eleventh year students of SMA Swasta Persiapan Stabat which totally consisted of 60 students in two classes. The concept of sample arises from the inability of the researchers to test all the individuals in a given population. The sample must be representative of the population from which it was drawn and it must have good size to warrant statistical analysis. By seeing the amount of population that was not too much, namely 36 students, thus the technique of sample withdrawal the writer resorted was total sample. So the total subjects of population were the sample in this study.

To acquire the data, a set of essay test was administered and distributed to the sample. The test consists of 2 items. The instrument of collecting data is test; two sets of test were administrated to the student. The tests were about temporal conjunction and procedure test writing from of test is multiple choices. The test of essay is that the students will make paragraphs.

\section{RESEARCH RESULT AND DISCUSSION}

This research used t-test. It compared means of the two groups by applying the t-test. The formula is as follows:

$$
\begin{aligned}
& \mathrm{t}=\frac{\mathrm{Ma}-\mathrm{Mb}}{\sqrt{\left[\frac{\mathrm{da}^{2}+\mathrm{db}^{2}}{\mathrm{Na}+\mathrm{Nb}-2}\right]\left[\frac{1}{\mathrm{Na}}+\frac{1}{\mathrm{Nb}}\right]}} \\
& \mathrm{Ma} \quad: \text { The mean of experimental group } \\
& \mathrm{Mb} \quad: \text { The mean of control group } \\
& \mathrm{da} \quad: \text { The standard deviation of experimental's score } \\
& \mathrm{db} \quad: \text { The standard deviation of control's score } \\
& \mathrm{Na} \quad: \text { The total number samples of experimental group } \\
& \mathrm{Nb} \quad: \text { The total number samples of control group. }
\end{aligned}
$$

The hypothesis testing is aimed at knowing whether the hypothesis is accepted or rejected. Based on result of the study is accepted. It is found from the computation of the ttest that t-observed ( 3.50$)$ is higher than t-table at the level of significance of $(p=0.05)$ 2.002. It meant that the hypothesis was accepted.

The result of analysis is 3.50. It is found out that the result of analysis is higher than ttable or it can be said $3.50>2.002$. It means that temporal conjunction more significantly effect on the students' descriptive writing achievement.

The formula of validity of the test that using scale scoring if $t$-value $\geq \mathrm{t}$-table or t-test $\geq \mathrm{t}$ table, the test was valid. From the test calculation, t-value was 3.50 and $t$-table was 2.002 , it can be concluded that the test was valid. 


\section{CONCLUSION}

The teaching of writing can be very pleasure and motivating if the students can focus their attention to the material of teaching. Focusing the attention of the material can be applied through methods based on student team achievement divisions. The researchers presence in the classroom made the students feel enjoy and fully participated in the teachinglearning process, because it can attract or motivate the student to improve their achievement in doing procedure text writing.

The data provides some valuable contribution to the teaching of writing to the grade XI students. Some main conclusions are made.

They are:

1). Temporal conjunction can give a positive effect on students' writing procedure text

2). Hypothesis of the study is accepted because the t-calculated is higher than t-table.

\section{REFERENCES}

Halimatussakdiah, "The Effect of Scrabble on Vocabulary Mastery of the Tenth Year Students of SMK TIK Jabal Rahmah Stabat," (Scholar Thesis, The English Department of Sekolah Tinggi Keguruan dan Ilmu Pendidikan Budidaya, Binjai, 2011.

Kier, June, Informative Texts. Greenwood: Ready-Ed Publication, 2009.

S. Peregoy, O. Boyle. Reading, Writing \& Learning in ESL: A Resource Book for K-12 Teachers. Vol. 3; New York: Longman, 2001.

Thomas, Linda, et al., Language, Society and Power: An Introduction. London: Routledge, 2004.

Quirk, Randolph, et al., A Comprehensive Grammar of the English Language. London: Longman, 2005.

Warner, Margaret. Easy Text Types. Greenwood: Ready-Ed Publication, 2009.

Weist, R.M. "Tense and Aspect," Language Acquisition: Studies in First Language Development, eds. P. Fletcher, M. Garman. Cambridge: Cambridge University Press, 2000. 